\title{
3Dプリンターの開発動向
}

\author{
京極 秀樹 ${ }^{1,2}$ \\ 1近畿大学 工学部ロボティクス学科 ( T739-2116 広島県東広島市高屋うめの辺1番) \\ ²技術研究組合次世代3D造形技術総合開発機構 (TRAFAM) ( ₹100-0005 東京都千代田区丸の内1-6-1)
}

\section{Recent Trend in Development of 3D Printer}

\author{
Hideki KYOGOKU ${ }^{1,2}$ \\ ${ }^{1}$ Faculty of Engineering, Kinki University, 1 Takaya-Umenobe, Higashihiroshima, Hiroshima 739-2116 \\ ${ }^{2}$ TRAFAM, 1-6-1 Marunouchi, Chiyoda-ku, Tokyo 100-0005
}

(Received August 3, 2014)

\begin{abstract}
Additive Manufacturing ( $\mathrm{AM}$ ) is attracting attention as a breakthrough technology in advanced manufacturing. In this paper, we describe the present state of the development of 3D printers for metals. AM technology, however, has issues that must be resolved: product accuracy, surface roughness, building volume, build-up rate, and so on. A national project, which was launched by the Japanese government in April 2014, is dedicated to the development of innovative 3D printers with electron beam and laser beam systems as well as the development of powder bed fusion and directed energy deposition processes. We introduced our ambitious objectives and the project's potential.
\end{abstract}

Key Words: Additive manufacturing, Laser sintering, Electron beam, Fabrication conditions, Mechanical properties

1. はじめに ${ }^{1-5}$

最近までRP(Rapid Prototyping), RM(Rapid Manufacturing) 等の名称で呼ばれてきた三次元造形(3D) 技術は, 2009 年のASTM (American Society for Testing and Materials) F42 委員会において, これらの技術を総称してAM(Additive Manufacturing) と呼ぶことが決定された.

本技術の最大の特徴は,

(1)従来の切削加工をはじめとする他の加工技術では不 可能な形状の製品の作製が可能な点であるが, その他,

(2)製品機能の統合化・個性化が可能

(3)ニーズへの素早い対応が可能 などの多くの利点を有するために, 切削加工, 鋳造など に次ぐ革新的な加工法として認識されてきた．AM技術 は上述の理由により，ものづくりにおける設計・製造の 考え方を変革してきつつある。

AM技術は, 1980年代に光硬化樹脂を用いた光造形技 術から端を発しているといわれており，金属材料につい ては，テキサス大学オースティン校で開発された選択的 レーザー焼結 (Selective Laser Sintering: SLS) 法による積 層造形技術が最初である ${ }^{6}$. 金属材料を対象とした積層 造形技術については，2000年代に入り，Fraunhofer ILT 研究所などを中心にレーザー光源の開発が着実になされ るとともに, 装置における粉末積層技術や粉末製造技術
の改善などが行われ，2008年に各社揃ってファイバレー ザーを搭載した金属積層造形装置が開発され，製品の高 密度化, 高強度化が図られるようになった。この頃か ら，アメリカでは2020年を睨んだロードマップの作成, ASTM F42委員会の立ち上げなどが行われた。 その後, オバマ大統領が，2012年に製造業の復活のための核とな る戦略としてAM(Additive Manufacturing) 技術開発なら びに人材教育に10億ドルを投資することを発表し,

NAMII (National Additive Manufacturing Innovation Institute), 現在のAmerica Makesを設立して以来, 我が 国をはじめ世界中で本技術に対する注目度が急速に高ま り，ドイッ，イギリスなどにおいても国家戦略を策定・ 実施してきている。ドイツFraunhofer ILT研究所を中心 としたヨーロッパ諸国では，すでに2006年にFANTASIA

(Flexible and near-net-shape generative manufacturing chains and repair techniques for complex shaped aero engine parts)プロジェクトにより航空機部品のLMD (Laser Metal Deposition) およびSLM(Selective Laser Melting)技術開発 を実施し, 多くの成果を得ている7).

このような背景のもと, 我が国においても三次元積層 造形技術，いわゆるAM技術が新たな加工法として注目 されるようになってきた。2013年度には, 経済産業省が このような $\mathrm{AM}$ 技術，いわゆる3Dプリンターへの関心の 高まりに呼応して「新ものづくり研究会」の立ち上げ，さ 
らには，「三次元造形技術を核としたものづくり革命プ

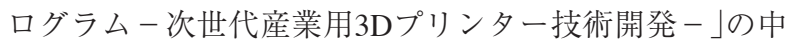
で，金属製品を対象とした国家プロジェクトを2014年度 に開始した。詳細は，後述する。

本稿では，金属3Dプリンターの現状と課題について 述べるとともに，国家プロジェクトの内容についてもそ の概要を紹介する。

\subsection{Dプリンターの現状と課題}

\section{$2.13 \mathrm{D}$ プリンターの現状}

AM技術は, ASTM F 42委員会により, Table 1に示す カテゴリーに分類されており，そのほかの規格について

も，ISOとともに規格化が進められている.

\section{(1) 粉末床溶融方式}

レーザー焼結 (SLS) あるいは溶融 (Selective Laser Melting: SLM) と呼ばれている方法で, 樹脂粉末及び金 属粉末の積層造形に利用されている. Fig. 1に選択的 レーザー積層造形法の模式図を示す。本法では, CAD データをSTLファイルに変換して，ガルバノスキャナー を介してレーザーを照射して，敷き詰めた粉末を焼結あ

Table 1 Additive manufacturing categories ${ }^{8)}$.

\begin{tabular}{ll}
\hline \multicolumn{1}{c}{ Category } & \multicolumn{1}{c}{ Description } \\
\hline Binder Jetting & $\begin{array}{l}\text { Liquid bonding agent selectively } \\
\text { deposited to join powder }\end{array}$ \\
\hline Material Jetting & $\begin{array}{l}\text { Droplets of build materials selectively } \\
\text { deposited }\end{array}$ \\
\hline Powder Bed Fusion & $\begin{array}{l}\text { Thermal energy selectively fused } \\
\text { regions of powder bed }\end{array}$ \\
\hline $\begin{array}{l}\text { Directed Energy } \\
\text { Deposition }\end{array}$ & $\begin{array}{l}\text { Focused thermal energy melts materials } \\
\text { as deposited }\end{array}$ \\
\hline Sheet Lamination & Sheet of material bonded together \\
\hline $\begin{array}{l}\text { Vat } \\
\text { Photopolymerization by light activation }\end{array}$ \\
\hline Material Extrusion & $\begin{array}{l}\text { Material selectively dispended through } \\
\text { nozzle or orifice }\end{array}$ \\
\hline
\end{tabular}

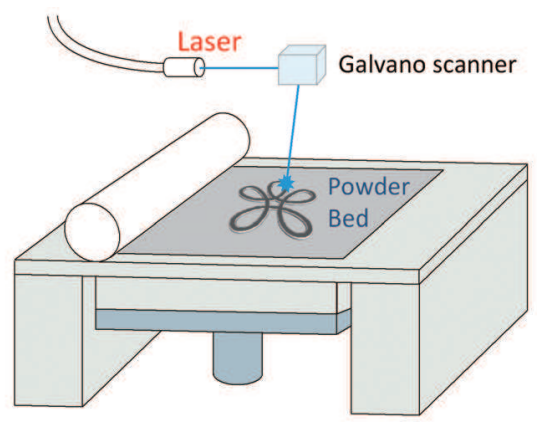

Fig. 1 Powder bed fusion.
るいは溶融する工程を繰り返すことにより積層造形を行 う方法である。本法では，金属においては，ほほ真密度 の造形体ができるようになっており，精度も50〜 $100 \mu \mathrm{m}$ 程度である。

最近の金属粉末を対象としたレーザー積層造形装置の 特徵は，高出力のファイバレーザーを搭載し，レーザー の高出力化が進んでいるともに, 多重光源化も行われて いる。代表的な金属粉末積層造形装置の仕様をTable 2 に 示す. 各社とも $200 \mathrm{~W}$ から $400 \mathrm{~W}$ Wァイバレーザーを 搭載する装置を開発している. SLM Solutions社では,

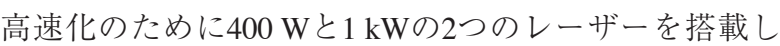
た装置を開発しており，造形速度の高速化が図られてき ている，金属レーザー積層造形装置については，海外 メーカーでEOS社 (ドイツ), Concept Laser社(ドイツ), SLM Solutions社(ドイツ), Renishaw社(英国), Phoenix 社(フランス) (2013年, 3D Systems社(アメリカ))などが ある。我が国では，(株)松浦機械製作所の装置があり， 切削機能を有している。これにより, 高精度・高機能金 型の作製が可能となっている.

一般的には, Table 2に示すように造形サイズ $\square 250 \mathrm{~mm}$ が主流ではあるが，例えば，歯科用材料や宝飾品のよう な小物の製作に関しては，各社から小型装置が開発され ている。これに対して，超大型装置では，Concept Laser 社がFraunhofer ILT研究所およびDimler社と共同開発した 超大型自動車試作品用装置が開発されており，大型化へ の傾向も見られる。なお，最近の装置の標準的な仕様を まとめると，次のとおりである。

・レーザー(ファイバレーザー：200～400 W)

·造形速度 $\left(\sim 20 \mathrm{~cm}^{3} / \mathrm{h}\right)$

. 造形精度 $(\sim 50 \mu \mathrm{m})$

. 造形精度 $(\sim 50 \mu \mathrm{m})$

・造形サイズ $(250 \times 250 \times 300 \mathrm{~mm}$ 程度 $)$

また, 電子ビームを光源とした積層造形装置は, ARCAM社 (スウェーデン)が唯一開発しており，当然の ことながら真空での造形となるため, 酸化が問題となる

Table 2 Specifications of metal 3D printers. ${ }^{\dagger}$

\begin{tabular}{|c|c|c|c|c|}
\hline Machine & $\begin{array}{c}\text { EOS } \\
\text { M280 }\end{array}$ & $\begin{array}{c}\text { SLM } \\
\text { SLM280HL }\end{array}$ & $\begin{array}{c}\text { Concept Laser } \\
\text { M2 }\end{array}$ & $\begin{array}{c}\text { 3D Systems } \\
\text { ProX300 }\end{array}$ \\
\hline Laser type & Fiber laser & Fiber laser & Fiber laser & Fiber laser \\
\hline Power (W) & 200 or 400 & $400 / 1000$ & 200 or 400 & 500 \\
\hline $\begin{array}{c}\text { Spot size } \\
(\mu \mathrm{m})\end{array}$ & $100 \sim$ & $70 \sim 120$ & $50 \sim 200$ & - \\
\hline $\begin{array}{l}\text { Scan speed } \\
(\mathrm{m} / \mathrm{s})\end{array}$ & $\sim 7$ & $\sim 15$ & $\sim 7$ & - \\
\hline $\begin{array}{l}\text { Layer thickness } \\
\qquad(\mu \mathrm{m})\end{array}$ & $20 \sim$ & $20 \sim 75$ & $20 \sim 80$ & $10 \sim 100$ \\
\hline $\begin{array}{l}\text { Build speed } \\
\left(\mathrm{cm}^{3} / \mathrm{h}\right)\end{array}$ & 20 & $20 \sim 35$ & $2 \sim 20$ & - \\
\hline
\end{tabular}

†装置の仕様については, 以下のホームページによる.

1) http://www.eos.info/systems_solutions/metal/systems_equipment/eosint_m280(2013.12.20現在)

2) http://stage.slm-solutions.com/index.php?slm-500_en(2013.12.20現在)

3) http://www.concept-laser.de/en/industry/automotive/machines.html (2013.12.20現在)

4) http://cweb.canon.jp/3dsystems/lineup/px/spec.html(2014.7.4現在) 


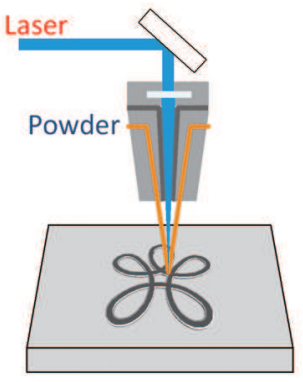

Fig. 2 Direct energy deposition.

チタンおよびチタン合金を中心としたインプラントや航 空・宇宙部品の製造などに利用され，急速に利用が拡大 してきている.

\section{（2）溶融堆積方式}

Fig. 2に示すように, 粉末をレーザーあるいは電子 ビームで溶融し, 溶融物を堆積させながら積層造形する 方法である.Sandia国立研究所の開発したLENS ${ }^{\circledR}$ 法, Fraunhofer ILT研究所で開発されたレーザー金属堆積 (Laser Metal Deposition: LMD) 法などがあり，実用機も 販売されている。最近では, 高精度や大型の製品の作製 も可能となってきている.

本法は，補修用として利用されているが，最近では積 層造形用としても利用され始めている。本法の特徵は, 精度や表面粗さは劣るものの, 単層ではなく多層や傾斜 材料の積層造形も可能であり，アスペクト比の大きい製 品の製造, 部分的な修復などが可能である。最近では, 真密度で複雑形状・大型品の作製が可能となっており, アルミニウム合金, ステンレス鋼, 工具鋼, チタン合金 などの材種にも対応できるようになっている，また，切 削加工との複合化を図った装置開発も行われている。製 品例としては，ブレード，ハウジング，金型など幅広い 分野の製品の製造が可能となってきている．製品例とし て, インコネル合金のジェットエンジン用タービンブ レードの例をFig. 3に示しておく.

\section{2 造形体の特性}

現在, 積層造形により造形される金属材料は, 装置の 性能向上により多種多様となってきている. 金属製品に 対応できる材種としては, 従来はステンレス鋼, 銅合金 が中心であったが, 最近では, 高速度工具鋼, 生体材料

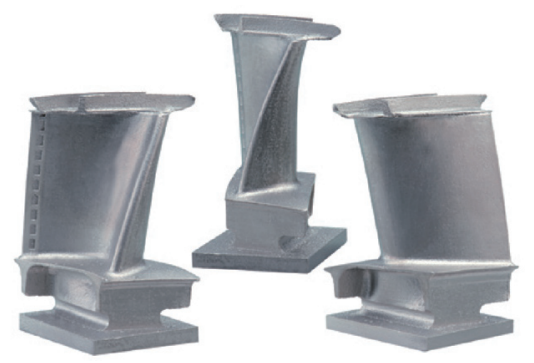

Fig. 3 Turbine blade of latest generation with internal conformal cooling channels to improve performance of jet engines (By the courtesy of SLM Solutions $\mathrm{GmbH}$ )
Table 3 Mechanical properties of SLMed metal and alloys used for implant applications (Referred by SLM Solutions Data Sheet).

\begin{tabular}{cccccc}
\hline $\begin{array}{c}\text { Metal or } \\
\text { Alloy }\end{array}$ & $\begin{array}{c}0.2 \% \text { Yield } \\
\text { strength } \\
(\mathrm{MPa})\end{array}$ & $\begin{array}{c}\text { Tensile } \\
\text { strength } \\
(\mathrm{MPa})\end{array}$ & $\begin{array}{c}\text { Elongation Hardness } \\
(\%)\end{array}$ & $\begin{array}{c}\text { Surface } \\
(\mathrm{HRC}) \\
\text { roughness } \\
\mathrm{Rz}(\mu \mathrm{m})\end{array}$ \\
\hline $\mathrm{Ti}$ & $>180$ & $>290$ & $>20$ & - & $36 \pm 4$ \\
\hline Ti-6Al-4V & $>865$ & $>972$ & $>10$ & 37.3 & $36 \pm 4$ \\
\hline $\begin{array}{c}\text { Co-Cr-Mo } \\
\text { (ASTM F75) }\end{array}$ & $>835$ & $>1050$ & - & 35 & $29 \pm 4$ \\
\hline $316 \mathrm{~L}$ & $525 \pm 30$ & $625 \pm 30$ & - & $237 \pm 4 \mathrm{HV}$ & $38 \pm 4$ \\
\hline $15-5 \mathrm{PH}$ & $1050 \pm 30$ & $1100 \pm 50$ & $16 \pm 432 \pm 3$ & $14 \pm 2$ \\
\hline H13 & - & 1730 & - & 54 & $34 \pm 4$ \\
\hline Al-12Si & 211 & 409 & 5 & $105 \mathrm{HB}$ & $34 \pm 4$ \\
\hline
\end{tabular}

用コバルトクロム合金，さらには航空宇宙用として利用 されている耐熱・耐食用インコネル合金, チタン合金, アルミニウム合金など幅広い材質の製造が可能となって きている。その例として，レーザー積層造形による造形 体の機械的性質および表面粗さの值をTable 3に示す。こ れからもわかるように，溶製材に匹敵する特性が得られ るようになってきている.

疲労強度は重要であるが, 十分に検討されているわけ ではない，とりわけ，電子ビームでは従来の溶製材とは 組織が異なることが報告されており，組織との関連も含 めて詳細な検討が必要である。

\subsection{Dプリンターの課題}

(1) ハードウェア

金属粉末を対象とした積層層造形装置については，上 述したように，さらなる高速化，高精度化㧍よび大型化 が求められている。現状では，製品化されている装置の 造型サイズは $\square 250 \mathrm{~mm}$ が標準であるため，適用製品が 限定されることから, 大型化への要望がある. 大型化に 際しては，多光源化が必要となり，これに伴って高速化 も要求される。このためには, レーザーや電子ビームの 高出力化も重要である。製品精度については，レーザー 光源の高品質化や照射パターンの最適化が必要となる. 表面粗さについても，鋳造品以上のものが求められてき ており,さらなる微細粉末を利用可能な積層技術の開発 などが必要となる。

溶融堆積方式の装置においては，精度や表面粗さの問 題があり，これが改善されれば，さらなる応用範囲が進 むものと考えられる。また，樹脂材料においては実現さ れてきている多種類の樹脂に対応した，多色化に対する 要求も求められてきている。金属材料においても，今後 多色化に対する研究開発が促進されるもの考えられる.

(2)ソフトウェア ${ }^{9,10)}$

積層造形においては，一般的にCADデータから形状 データをSTLデータに変換して, CAD上で3Dモデリン グを行った後，スライスデータを作成して，レーザーや 電子ビームを操作して造形する。この際に，STLデータ 
の精度が問題となっており, 高精度化のための取り組み が行われている。また，STLデー夕は座標值のみである ため, ASTM F42委員会では, AMFフォーマットの提案 を行っており, 今後このフォーマットへの変換も必要で ある。

また，本技術の最大の特徴は，従来法では不可能で あった三次元複雑形状で，かつ表面および内部構造をま で考慮した製品の製造ができる点である，すなわち，位 相最適化法などのシミュレーションにより設計された製 品の作製や人体などの複雑な 3 次元形状をCTなどで読み 取り，データ変換を施すことによりインプラントを作製 できるなど, 従来の加工法では不可能な形状の製品を加 工できる，切削加工においては，基本的に表面デー夕を 扱うが，三次元積層造形法では，表面および内部構造の 両方を取り扱うことができるため，表面へのテクスチャ の付与が可能であり, 内部をメッシュ構造やラティス構 造, さらには傾斜構造にすることも可能である. 現在, 盛んにこのような内部構造や表面テクスチヤの記述に対 応できるソフトウェアの開発が行われており, 今後も重 要な課題である.

\section{（3）金属粉末}

金属粉末については，装置メーカーが粉末を指定する ことが多く，このため材質的にも制限される場合が多い ことから, ユーザーの要求にあった仕様となっていない 点が問題となっている。しかし，欧州においては，いち 早くAM用粉末の開発を行っており，昨年(2013年) AS9120(航空宇宙)の認証を受けた粉末製造メーカーも ある。

金属粉末の粒径, 粒度分布などの特性と造形条件の関 連性については十分に把握されているとは言えず，また 装置の仕様に依存する点も多い.このため, 粉末特性と 造形条件を考慮した最適条件を示すプロセスマップ，い わゆるレシピの作成が重要である。この際には, 溶融凝 固解析等も行っておくことが重要である.

\section{3. 次世代型産業用3Dプリンター技術開発}

\section{1 事業の背景および目的}

上述した「新ものづくり研究会」報告書 ${ }^{11)}$ にもるよう に，新たなものづくりのための設計・製造プロセスの革 新は, 我が国におけるものづくりにおいて極めて重要で ある。

このため, 我が国においても, ものづくり産業がグ ローバル市場において持続的かつ発展的な競争力を維持 するために，地域の中小企業等の持つ技術や資源を活用 し，少量多品種で高付加価值の製品・部品の製造に適し た三次元積層造形技術や金属等の粉体材料の多様化 ·高 機能複合化等の技術開発及びその周辺技術の開発を行 い, 次世代のものづくり産業を支える三次元積層造形シ ステムを核とした我が国の新たなものづくり産業の創出 を目指すことを目的として, 技術研究組合次世代 $3 \mathrm{D}$ 造 形技術総合開発機構(通称, TRAFAM) が設立され, 国
家プロジェクトとして経済産業省「三次元造形技術を核 としたものづくり革命プログラム」が2014年度より5年計 画で開始された。

\section{2 開発目標}

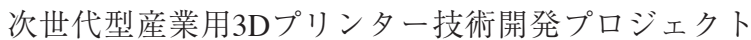
の目標は，世界最高水準の三次元積層造形装置を開発す ることで, 装置の高速化, 高精度化, 大型化さらには複 層化を目指すものである，光源には，電子ビームとレー ザービームの2種類を採用して，Table 4に示すような目 標を達成するものである。

\section{3 事業内容}

国家プロジェクトで求められている技術開発内容は, 次のとおりである。

（1）電子ビーム及びレーザービーム共通

(1)異種金属を傾斜構造で積層することを可能とする.

(2)装置で使用する積層造形用の制御ソフト等を開発す る.

(3)粒径50 $\mu \mathrm{m}$ 以下の金属粉体の使用を可能とする.

(2) 電子ビーム

(1)電子ビームの出力は $5 \mathrm{~kW}$ 以上, ビーム径は $100 \mu \mathrm{m}$ 以下.

(2)電子ビームコラム陰極の耐久時間は1,000時間以 上.

(3)加工室の真空度は $1 \times 10^{-2} \mathrm{~Pa}$ 以下.

（3）レーザービーム

(1)レーザーの出力 $2 \mathrm{~kW}$ 以上.

(2)高速パルス駆動技術の開発.

(3)ガルバノミラーの高速化, 数台対応技術開発.

（4）金属等粉末開発及び粉末修飾技術開発

(1)金属粉末の粒径分布の狭幅化，微細化技術の開発.

(2)鉄系，銅系，ニッケル系，チタン系，コバルト系等 3Dプリンター用金属粉末の製造技術の確立.

(3)高温耐熱合金，耐食合金などの新合金材料を，当該 産業用3Dプリンターにおいて使用できる技術の確 立.

(4)金属粉末の高品質及び低コスト化技術の開発.

(5)防錆等粉末修飾技術及び傾斜材料用粉末製造技術の 確立.

(6) チタン系及び新材料合金を除く各種金属粉体につい

Table 4 Objectives of the national project.

\begin{tabular}{ccccc}
\hline Type & $\begin{array}{c}\text { Source } \\
\text { type }\end{array}$ & $\begin{array}{c}\text { Build chamber size } \\
(\mathrm{mm})\end{array}$ & $\begin{array}{c}\text { Build } \\
\text { speed } \\
(\mathrm{cc} / \mathrm{h})\end{array}$ & $\begin{array}{c}\text { Accuracy } \\
(\mu \mathrm{m})\end{array}$ \\
\hline Type I & EB & $\begin{array}{c}\text { Large-sized } \\
(1000 \times 1000 \times 600)\end{array}$ & 500 & 50 \\
\hline Type II & EB & $\begin{array}{c}\text { Middle-sized } \\
(300 \times 300 \times 600)\end{array}$ & 500 & 20 \\
\hline Type III & LB & $\begin{array}{c}\text { Large-sized } \\
(1000 \times 1000 \times 600)\end{array}$ & 500 & 20 \\
\hline $\begin{array}{c}\text { Type IV } \\
\text { (Deposition type })\end{array}$ & LB & $\begin{array}{c}\text { Middle-sized } \\
(300 \times 300 \times 300)\end{array}$ & 500 & 20 \\
\hline & & & &
\end{tabular}


ては，粒径 $20 \mu \mathrm{m}$ 以下のものを使用できるよう実用 化開発する。

（5）周辺技術 (高機能複合部材の開発, 後加工, 未使用 粉末の回収等技術) 開発

(1)爆発防止等, 装置の安全性対応技術の開発.

(2)造形物の自動搬出・ブラスト, 粉体自動供給, 金属 粉体分離, 不要粉体自動回収機構等周辺装置の開 発.

(3)造形物の精度向上に資する最適な後処理加工技術の 開発.

(4)高機能複合部材の開発及び積層条件等の検討.

(5)粉末の高性能分級技術の検討.

\section{$3.43 \mathrm{D}$ 積層造形技術開発}

上記技術開発課題を解決し, 開発目標を達成するため に, TRAFAMにおいて, 次の3Dプリンター開発, 金属 粉末開発および制御ソフトウェア開発を行う。本プロ ジェクトにおいては, 光源を電子ビームとレーザービー ムの2種類として，つぎのような技術開発を行ってい る. なお, レーザービーム方式では, 粉末床溶融方式と 溶融堆積方式の2種類の装置開発を行っている.

(1) 電子ビーム方式3D積層造形装置技術開発

(1)要素技術研究開発

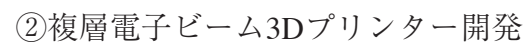

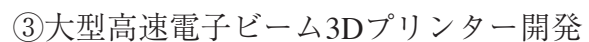

（2）レーザービーム方式3D積層造形装置技術開発

(1)要素技術開発

(2)複層レーザービーム3Dプリンター開発

(3)大型高速レーザービーム $3 \mathrm{D}$ プリンター開発

（3）金属粉末開発および粉末修飾技術開発

(1)新アトマイズ法による高融点・高活性金属粉末製造 技術の開発

(2)気体流による遠心分離方式金属粉末分離機構の開発

(3)高機能粉末製造のための粉末修飾技術の開発

(4) 3Dプリンター制御ソフトウェア開発

(1)各種フォーマットにおけるデータ処理ソフトウェア の開発

(2)加工条件設定・最適パス生成技術の開発

\section{4. おわりに}

金属AM技術のここ数年の進展は目覚ましく, レー
ザー性能の向上, ソフトウェアの開発などによる装置の 高機能化，粉末製造技術の向上などにより自動車，航空 宇宙分野から医療分野までの新たな加工技術として，認 識されてきた。しかしながら，その核となる金属3Dプ リンターの性能については，ユーザーからみると不満足 な点も多く, 造形品の高精度化および造形速度の高速化 が可能なだけでなく，操作性に優れるソフトウェアを搭 載した装置開発が求められている。また，金属粉末の材 質においてもその種類は増えてきているが，今後はAM 技術に相応しい材料設計を行っていく必要もある。

このような背景のもと，2014年度より開始された経済 産業省の国家プロジェクトでは，世界最高水準の次世代 型産業用3Dプリンターの開発を目標としている。本プ ロジェクトにおいて，我が国の企業に相応しい装置開発 がされれば，ものづくりにおける設計・製造技術の革新 がなされるものと期待される。このためには, ユーザー 側の本技術に対する理解とものづくりにおける設計・製 造技術の变革が行われなければ，真の变革とはならな い.また，これを実現していくためには，今後人材育成 を含めた国としての施策が重要である。

\section{参考文献}

1) 京極 秀樹：近畿大学次世代基盤技術研究所報告 5 (2014) 139.

2) 京極 秀樹：溶接学会誌 83 (2014) 250.

3）京極 秀樹：型技術 25 (2010) 23.

4) 新野俊樹：型技術 25 (2010) 18.

5) 丸谷洋二ほか：積層造形技術資料集（オプトロニクス社, 2002).

6) J. J. Beaman, J. W. Barlow, D. L. Bourell, R. H. Crawford, H. L. Marcus, and K. P. McAlea: Solid Freeform Fabrication: A New Direction in Manufacturing (Kluwer Academic Publishers, 1997), p.23.

7) A. Gasser, G. Backes, I. Kelbassa, A. Weisheit, and K. Wissenbach: Laser Material Processing (2010) 58.

8) Standard Terminology for Additive Manufacturing Technologies, ASTM Standard F2792-12a (2012).

9) E. Dhoole: Advanced Manufacturing Technology for Medical Applications edited by I. Gibson (John Wiley \& Sons, 2005).

10) I. Gibson, D. W. Rosen, and B. Stucker: Addituve Manufacturing Technologies - Rapid Prototyping to Direct Digital Manufacturing - (Springer, 2010).

11）経済産業省「新ものづくり研究会」報告書(平成26年2月), (2014). 